\title{
Individual Goals, Neighborhood Context
}

Ann Fam Med 2016;14(2):iii. doi:10.1370/afm.1927.

$\mathrm{T}$ The Annals of Family Medicine encourages readers to develop a learning community of those seeking to improve health care and health through enhanced primary care. You can participate by conducting a RADICAL journal club and sharing the results of your discussions in the Annals online discussion for the featured articles. RADICAL is an acronym for Read, Ask, Discuss, Inquire, Collaborate, Act, and Learn. The word radical also indicates the need to engage diverse participants in thinking critically about important issues affecting primary care and then acting on those discussions. ${ }^{1}$

\section{HOW IT WORKS}

In each issue, the Annals selects an article or articles and provides discussion tips and questions. We encourage you to take a RADICAL approach to these materials and to post a summary of your conversation in our online discussion. (Open the article online and click on "TRACK Comments: Submit a response.") You can find discussion questions and more information online at: http://www.AnnFamMed.org/site/AJC/.

\section{CURRENT SELECTION}

Ferrer RL, Burge S, Palmer RF, Cruz I. Practical opportunities for healthy diet and physical activity: relationship to intentions, behaviors, and body-mass index. Ann Fam Med. 2016;14(2):109-116.

\section{Discussion Tips}

This article provides an opportunity to raise our gaze from trying to help individuals to make prudent choices in behaviors that affect their health, to consider the contextual factors that affect the practical constraints and opportunities that affect patients' choices.

\section{DISCUSSION QUESTIONS}

- What question is asked by this study and why does it matter?

- How does this study advance beyond previous research and clinical practice on this topic?
- How does it build on prior work by these authors on this topic? $?^{2,3}$

- How strong is the study design for answering the question?

- To what degree can the findings be accounted for by:

1. How patients were selected, excluded, or lost to follow-up?

2. How the main variables were measured? (What do you think of the process used to refine the independent variable? Does the range of dependent [outcome] variables add to the robustness of the findings?)

3. Confounding (false attribution of causality because 2 variables discovered to be associated actually are associated with a 3 rd factor)?

4. Chance?

5. How the findings were interpreted?

- What are the main study findings?

- How comparable is the study sample to similar patients in your practice? What is your judgment about the transportability of the findings? (Note that the study was done in a practice-based research network of residency training practices.)

- What contextual factors are important for interpreting the findings?

- How might this study change your practice? Policy? Education? Research?

- Who are the constituencies for the findings, and how might they be engaged in interpreting or using the findings?

-What are the next steps in interpreting or applying the findings?

-What researchable questions remain?

\section{References}

1. Stange KC, Miller WL, McLellan LA, et al. Annals Journal Club: It's time to get RADICAL. Ann Fam Med. 2006;4(3):196-197. http:// annfammed.org/cgi/content/full/4/3/196.

2. Ferrer RL, Carrasco AV. Capability and clinical success. Ann Fam Med 2010;8(5):454-460. http://www.annfammed.org/content/8/5/454. full.

3. Ferrer RL, Cruz I, Burge S, Bayles B, Castilla MI. Measuring capability for healthy diet and physical activity. Ann Fam Med. 2014; 12(1):46-56. http://www.annfammed.org/content/12/1/46.full. 